\title{
The Effect of Increased Food Supply on the Body Growth Rate and Survival of Bank Voles in an Island Population
}

\begin{abstract}
Krzysztof BANACH
Banach K., 1986: The effect of increased food supply on the body growth rate and survival of bank voles in an island population. Acta theriol., 31, 3: 45-54 [With 3 Tables \& 4 Figs.]

Studies were made of the effect of increased food supply on the growth rate and survival of members of an island population of the bank vole Clethrionomys glareolus (Schreber, 1780), for which purpose comparison was made of the mean weight of individuals, increase in their weight in dry and wet habitats, and survival during the period 1966-1969, when the population was living in natural conditions, and from 1973-1974, when the voles were supplied ad lib. with oats. It was found that during the supplementary feeding period the mean weight of the animals was significantly greater than in years when they fed on the natural food supply only. From 1966-1969 increase in weight was greater in the animals living in the wet habitat. During the experiment, growth rate was uniform in both dry and wet habitats. Survival between trapping series was greater from 1973-1974 than from 1966-1969.

[Institute of Ecology, Polish Academy of Sciences, Dziekanów Leśny, 05-992 Łomianki, Poland].
\end{abstract}

\section{INTRODUCTION}

A large number of authors have drawn attention to the small extent to which the available food supply is consumed by small forest rodents (Górecki \& Gębczyńska, 1962; Ryszkowski, 1969; Gębczyńska, 1970; Grodziński, 1971a, and others).

In the temperate climate zone, apart from cases of mass irruption of rodents, from $0.5-3 \%$ of the available food supply is consumed by rodents, whereas in the taiga this figure is $5-7 \%$ (Grodziński, 1961). The natural food supply during the growing season is greatly in excess of rodents' food requirements, even during the final phase of winter, and thus food is not a factor directly limiting the numbers of small rodents in forests (Górecki \& Gębczyńska, 1962; Grodziński, 1963). In years with large seed crops (beech, oak) the population numbers of rodents are, however, much greater than in years with a poor supply of seeds (Bobek, 1969; Hansson, 1971a, and others). This has been proved experimentally by Bendel (1959) in the case of Peromyscus leucopus novoboracensis (Fischer, 1829) and Andrzejewski (1975) in the case of Clethrionomys glareolus (Schreber, 1780). Increased reproduction was also 
observed (Watts, 1970) and greater accumulation of fat by rodents (Andrzejıwski, 1975).

The material used in the present study has already formed the subject of numerous analyses (Andrzejewski, 1975; Bock, 1972; Bujalska, 1975, 1975a; Bujalska \& Gliwicz, 1972; Gliwicz et al., 1968; Mazurkiewicz, $1972,1981)$. During the experiment with supplementary feeding the size of home ranges of rodents was observed to decrease, while the degree to which they overlapped increased, showing that mutual tolerance increased among the animals (Mazurkiewicz \& Andrzejewski, 1976).

The purpose of the present study was to establish whether experimentally increased food supply in an island population of Clethrionomys glareolus affects the growth rate and survival of members of the population

\section{STUDY AREA AND METHODS}

\subsection{Study Area}

The studies were carried out during the period from 1966-1969 and 1973-1974 as part of a group research on a bank vole population, Clethrionomys glareolus (Schreber, 1780), inhabiting an island 4 ha in area in Lake Beldany in the northeast of Poland $\left(53^{\circ} 40^{\prime} \mathrm{N}, 21^{\circ} 35^{\prime} \mathrm{E}\right)$. The bank vole was the only rodent species living on the island.

The island is covered by woods belonging to three phytosociological associations. The middle part of the island, which is also the highest and driest ground, is covered by Tilio-Carpinetum (Traczyk, 1962). In the wet depressions of the island this association changes to Circaeo-Alnetum (Oberdorfer, 1963). The edge of the island is occupied by Salici-Franguletum (Malc. 1923) (Traczyk, 1965). The tree stand growing on the island was untouched by human management and therefore had a well-developed layer and age structure, the oldest trees being about 150 years old. This is a typical habitat of C. glareolus (Gębczyńska, 1983). The population enjoyed good living conditions, as is shown by its relatively high density (39.2 to 92 individuals/ha) during the peak numbers in July.

\subsection{Methods}

Data on the vole population was obtained by the CMR method. The live traps were baited with oats to attract the animals, and were inspected twice daily at 7.00 and 19.00, making a note during each inspection of the trapping site of the individual number of the animal, its sex and weight, and then releasing it on the place of its capture. Five trapping series were carried out at 6 -weekly intervals each year from spring to autumn. During the period from 1966-1969 each series lasted 14 days and from $1973-1974$ from 10 to 14 days.

In order to evaluate the changes taking place in the population as a result of experimentally increasing the food supply in the habitat, comparison was made of increase in weight and survival of individuals from 1966-1969, when the 
population fed solely on the natural food supply, with the results obtained from the spring of 1973 to autumn of 1974, when additional food (oats) was made available.

The rodents were given supplementary food on 159 evenly distributed trapping sites at a distance of $15 \mathrm{~m}$ from each other. During the supplementary feeding period a box with an entrance, containing about $3 \mathrm{~kg}$ of oats, was placed on each trapping site, and was exchanged for a fresh box after the rodents had consumed half the oats. The animals had unhindered access to the food throughout the experiment, except for the period when trapping was being carried out, when $2-5$ live traps were set on each trapping site. The number of traps on a site depended on the current numbers of the vole population.

\subsection{Dynamics of Population Numbers}

The numbers of bank voles were estimated by the "general census" method of individuals caught during each trapping series (Andrzejewski \& Petrusewicz, 1962). Several groups of animals born during the current breeding season, termed cohorts $(\mathrm{K})$ were distinguished according to the time of their entry into the trappable part of the population (Gliwicz et al., 1968).

Number dynamics of the study population exhibited a two-year cycle of numbers during the years when only natural fond was available. Peak numbers occurred, in July, with 302 animals in 1966 and 368 in 1968. In 1967 and 1969 (characterized by absence of any distinct peak in numbers) these figures in July were respectively 172 and 157 (Andrzejewski \& Rajska, 1972; Gliwicz, 1975; Bujalska, 1975). During the experimental years (1973-1974) the numbers of bank voles were several times greater than in the years when they made use of the natural food supply only.

A peak in numbers also occurred in July and in 1973 there were 1068 individuals and 835 in 1974 (Andrzejewski \& Mazurkiewicz, 1976; Mazurkiewicz, 1981)
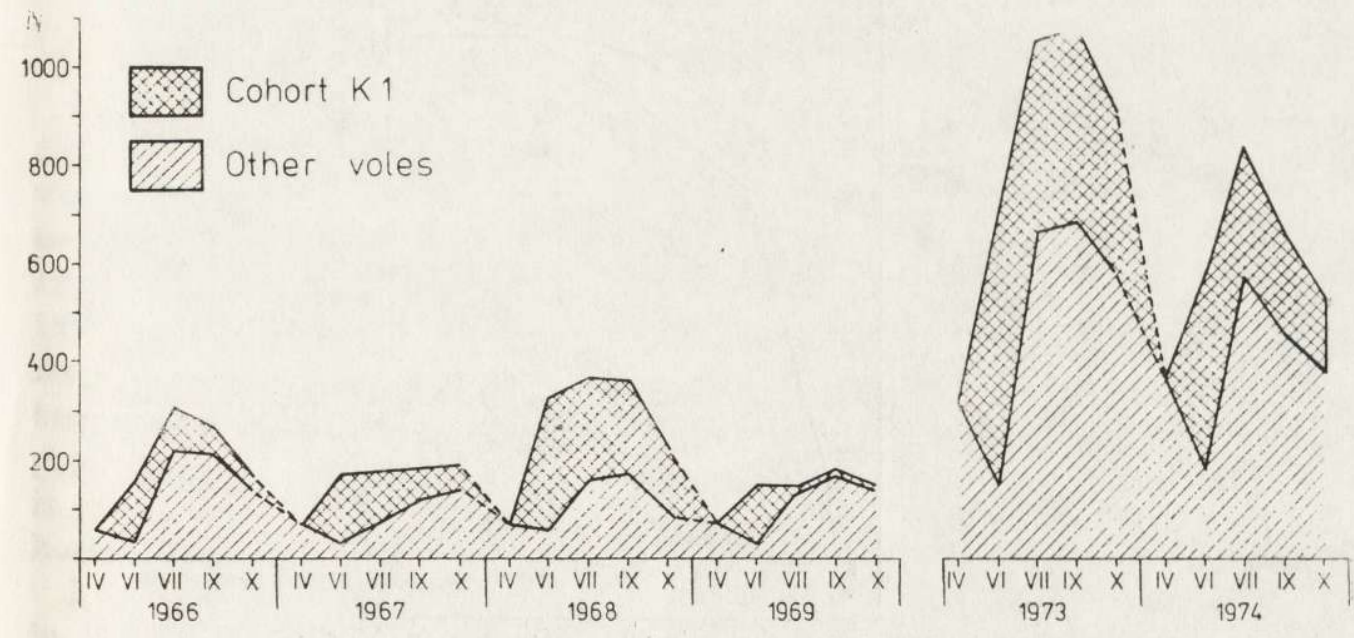

Fig. 1. Dynamics of numbers of a population of Clethrionomys glareolus living on an island (after Mazurkiewicz \& Andrzejewski, 1976). 
(Fig. 1). In these last two years the population differed not only in the number of overwintered, but also in the number of animals born during the year (marked at an age of $6 \pm 3$ weeks, and in the size of cohort $\mathrm{K}_{1}$ which was analyzed in detail (Table 1).

Table 1

Numbers of individuals recorded in the population and size of cohort $\mathrm{K}_{1}$.

\begin{tabular}{ccc}
\hline Year & $\begin{array}{c}\text { Number of marked individuals } \\
\text { N }\end{array}$ & $\begin{array}{r}\text { From } \\
\mathrm{K}_{1} \text { only }\end{array}$ \\
\hline 1966 & 364 & 114 \\
1967 & 343 & 123 \\
1968 & 508 & 290 \\
1969 & 358 & 122 \\
1973 & $1306^{1}$ & 541 \\
1974 & 980 & 386 \\
\hline
\end{tabular}

1 After Mazurkiewicz \& Andrzejewski, 1976

\section{RESULTS}

\subsection{Growth Rate and Body Weight of Individuals}

In order to ascertain whether increase in food supply affects the weight of the youngest animals in the population, the mean weight was calculated for all individuals at the time of marking ( $6 \pm 3$ week of life)

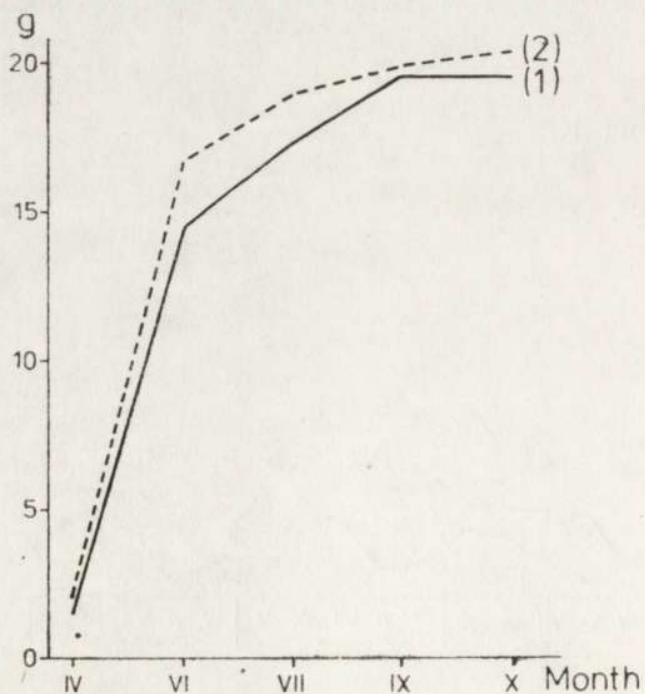

Fig. 2. Increase in body weight of voles in cohort $K_{1}$ under natural conditions (1) and experimental conditions (2). 
caught during the years when only the natural food supply was available, or during the experiment. It was found that during the experiment the mean weight of newly-marked individuals $(17.2 \mathrm{~g})$ was significantly higher $(0.001<p<0.01)$ than in the years with the natural food supply $(13.9 \mathrm{~g})$.

This increase was greatest during the first period of life of cohort $K_{1}$ (Fig. 2). The further course of cohort $K_{1}$ was traced over the growing season, comparing growth curves obtained for the years with natural food supply and the experimental years. As the difference in mean weights of individuals is not significant for the period 1966-1967, these years have been treated jointly in the further part of this paper, and the same procedure has been used for 1973 and 1974 .

As cohort $\mathrm{K}_{1}$ grew older the rate of increase in body weight of these animals became increasingly slower. Towards the end of the growing season (October) the differences between the body weight of individuals from the natural food supply years and that of animals from the experimental years disappeared (Table 2).

Table 2

Mean weight (g) of individuals in cohort $\mathrm{K}_{1}$ in successive trapping series in different years.

\begin{tabular}{lcccc}
\hline Year & June & July & Sept. & Oct. \\
\hline $1966, \quad 1967$ & 14.4 & 18.4 & 19.6 & 19.4 \\
1968 & 13.2 & 16.4 & 17.9 & 18.7 \\
$1969 \quad 1974$ & 16.5 & 20.2 & 20.4 & 20.6 \\
$1973, \quad 19.8$ & 16.8 & 19.0 & 19.9 & 20.6 \\
\hline
\end{tabular}

It was found that in the case of the population living under natural conditions in a year of high numbers (1968) the weight of individuals was lower than in the year of low population numbers (1969). It was to be expected that with very high population numbers in 1973 and 1974 the weight of individuals would be similar to that observed in 1968, whereas it was very high and similar to the weight for 1969 . As a result of the more abundant food supply in the habitat individuals belonging to cohort $\mathrm{K}_{1}$ attained greater body weights, regardless of population numbers (Table 3). It is an accepted fact that a wet habitat is the optimum for the bank vole (Wrangel, 1939; Turček, 1960; Chelkowska, 1969; Bock, 1972; Gębczyńska, 1983).

Investigation was therefore made to determine whether an increase in food supply affects to a similar degree the rate of increase in body weight of trappable animals living in dry-sub-optimum (Tilio-Carpinetum) and those living in wet-optimum (Circaeo-Alnetum and Salici- 
Table 3

Mean weight of individuals in cohort $\mathrm{K}_{1}$ during thee growing season.

\begin{tabular}{lrcc}
\hline Food supply & Year & $\begin{array}{c}\text { Population } \\
\text { numbers }\end{array}$ & $\begin{array}{c}\text { Mean wt., g } \\
\text { (cohort } \mathrm{K}, \text { ) }\end{array}$ \\
\hline Natural & 1968 & high & 16.5 \\
& 1966,67 & medium & 17.9 \\
Experimental & 1969 & low & 19.4 \\
\hline
\end{tabular}

Franguletum) habitats of the island. Comparison of the mean percentage increase in body weight of $\mathrm{K}_{1}$ animals between successive trapping series in these two types of habitat (Fig. 3) shows that during the years
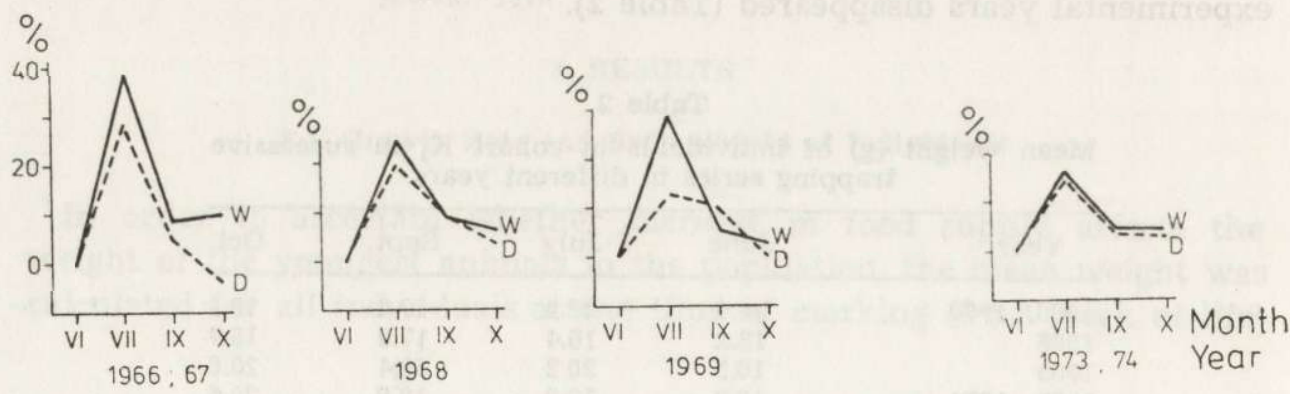

Fig. 3. Increase in body weight of individuals in cohort $\mathrm{K}_{1}$ in percentages, in wet (W) and dry (D) habitats.

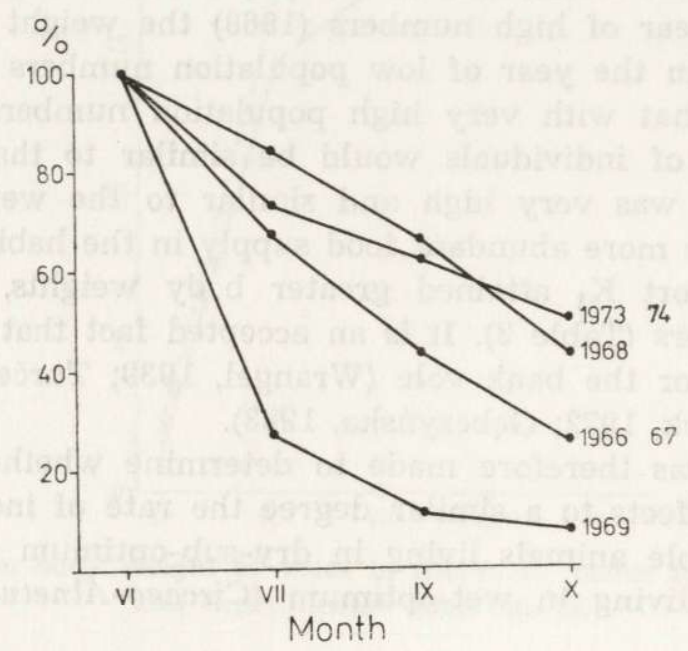

Fig. 4. Survival of cohort $\mathrm{K}_{1}$ in percentages in different years. 
of natural food supply body weights in the wet habitat were higher than in the dry habitat. This was particularly distinct during the years of low density $(1967,1969)$ whereas in years with the experimentally increased food supply the rate of increase in body weight was identical in both habitats and was similar to that in 1968 (when the population density was high).

\subsection{Survival}

Examination was made of the effect of increased food supply on the survival of cohort $\mathrm{K}_{1}$ between different trapping series. It was found that in the years with the natural food supply the survival of animals belonging to cohort $\mathrm{K}_{1}$ was lowest in 1969 , when numbers were lowest and it was highest in 1968, when numbers were highest (Fig. 1). During the experimental years survival during the initial period of the cohort's life (June-September) was lower than in 1968, but was higher during the final period of the season (September-October). In effect, the highest percentage of $K_{1}$ individuals survived up to the end of the seaason under conditions of increased food supply (Fig. 4).

\section{DISCUSSION}

The material presented above shows that increase in numbers is ensured by increased reproduction and by increased survival. Evidence for an increase in the former is shown by the 3-4 times greater number of young animals entering the population from an age of $6 \pm 3$ weeks during the reproduction season.

It is difficult to determine, on the basis of the material available, to what degree increase in the number of individuals entering the trappable part of the population depends on an increase in reproduction rate of the population, and to what degree on reduction in nest mortality, which in the years with only the natural food supply exerted a decisive effect on the dynamics of population numbers.

Survival of trappable animals during the experimental years was high, although in certain periods of the season it did not exceed the maximum survival observed in the years with natural food supply. It would appear that there is a positive relation between the survival of cohort $\mathrm{K}_{1}$ and the population density. Bujalska (1975) noticed a similar relationship. It must, however, be remembered that only the survival of cohort $\mathrm{K}_{1}$ has been analyzed in this paper. As shown by earlier studies (Bujalska, 1975; Gliwicz, 1976) animals from the generation born during the first half of the growing season (that is, cohorts $K_{1}$ and $K_{2}$ ) 
in the years with high population numbers, are characterized by better survival than animals from the autumn generation; in years with low population numbers survival is poorer and similar for the two generations (Bujalska, 1975).

Experimental increase of the food supply causes significant changes in the body weight of the animals. The natural food supply is not sufficient for simultaneous increase in population numbers and rapid rate of individual growth.

It has been found that under experimental conditions of increased food supply, the individual growth rate in the "better" and "worse" habitats was identical. It can thus be concluded that the equalization of food conditions in these two habitats was one of the possible factors accounting for increase in the growth rate and mean body weight of individuals in the years of high population numbers. In addition, the dry habitat with enriched food supply, was better for the voles in 1973 and 1974 than in the previous years. In other words the almost unlimited food supply in the habitat, as can be concluded from the small proportion of available food consumed by the voles (Górecki \& Gębczynska, 1962), was only apparent.

\section{REFERENCES}

1. Andrzejewski R. \& Rajska E., 1972: Trappability of bank vole in pitfalls and live traps. Acta theriol., 17: $41-56$.

2. Andrzejewski R., 1975: Supplementary food and the winter dynamics of bank vole populations. Acta theriol., 20: 23-40.

3. Bendel J. F., 1959: Food as a control of a population of white footed mice, Peromyscus leucopus novoboracensis (Fischer). Can. J. Zool., 37: 173-209.

4. Bobek B., 1969: Survival, turnover and production of small rodents in beech forest. Acta theriol., 14: 191-210.

5. Bock E., 1972: Use of forest associations by bank vole population. Acta theriol., 17: 203-219.

6. Bujalska G., 1975: Reproduction and mortality of bank voles and the changes in the size of an island population. Acta theriol., 20: 39-54.

7. Bujalska G. \& Gliwicz J., 1972: Growth and reproduction of female bank vole under field conditions. Acta theriol., 17: 33-40.

8. Chelkowska H., 1969: Numbers of small rodents in five plant associations. Ekol. pol. A, 17: 847-854.

9. Gębczyńska Z., 1970: Bioenergetic of a root vole populations. Acta theriol., 15: $33-66$.

10. Gębczyńska Z., 1983: Feeding habits. [In: "Ecology of the bank vole", Ed. K. Petrusewicz]. Acta theriol., 28, Suppl. 1: 40-49.

11. Gliwicz J., Andrzejewski R., Bujalska G. \& Petrusewicz K., 1968: Productivity investigation of an island population of Clethrionomys glareolus (Schreber, 1780). I. Dynamics of cohorts. Acta theriol., 13: $401-413$. 
12. Gliwicz J., 1975: Age structure and dynamics of numbers in an island population of bank voles. Acta theriol., 20: 57-69.

13. Gliwicz J., 1976: Differentiation of survival in bank vole population. Bull. Acad. pol., Sci., Cl. II, 6: 325-351.

14. Górecki A. \& Gębczyńska Z., 1962: Food conditions for small rodents in a deciduous forest. Acta theriol., 6: 275-295.

15. Grodziński W., 1961: Metabolism rate and bioenergetics of small rodents from the deciduous forest. Bull. Acad. pol. Sci., Cl. II, 9: 439-499.

16. Grodziński W., 1963: Can food control the numbers of small rodents in the deciduous forest. Proc. XV Int. Congr. Zool., 1: 257-288. Washington.

17. Grodziński W., 1971a: Energy flow through populations of small mammals in the Alaskan taiga forest. Acta theriol., 16: 231-275.

18. Hansson L., 1971a: Small rodent food, feeding and population dynamics. A comparison between granivorous and herbivorous species in Scandinavia. Oikos, 22: $183-198$.

19. Mazurkiewicz M., 1972: Density and weight structure of populations of the bank vole in open and enclosed areas. Acta theriol., 17: 455-465.

20. Mazurkiewicz M. \& Andrzejewski R., 1976: Abundance of food supply and size of the bank voles home range. Acta theriol., 21: 237-252.

21. Mazurkiewicz M., 1981: Spatial organization of role bank vole population in years of small or large numbers. Acta theriol., 26: 31-45.

22. Ryszkowski L., 1969: Estimates of consumption of rodent populations in different pine forest ecosystems IIn: "Energy flow through small mammal populations", Eds. K. Petrusewicz \& L. Ryszkowski]. Pol. Sci. Publ.: 281-289. Warszawa.

23. Traczyk H., 1965: The vegetation of "The Wild Apple-Tree Island" on the Lake Bełdańskie (North-Eastern Poland). Fragm. flor. geobot., 11: 541-545.

24. Turček F. J., 1960: Sidelne vztahy nekotorych drobnych chlodavcov zistene na poklade mapovania. Biologia, 15:

25. Watts C. H. S., 1970: Effect of supplementary food on breeding in woodland rodents. J. Mammal., 51: 169-171.

26. Wrangel H., 1939: Beiträge zur Biologie der Rötelmaus, Clethrionomys glareolus (Schreber, 1780). Z. Säugetierkde, 14: 54-93.

Accepted, September 5, 1985.

\section{Krzysztof BANACH}

\section{WPEYW ZWIEZKSZONEJ BAZY POKARMOWEJ NA TEMPO WZROSTU I PRZEZYWALNOSC OSOBNIKOW W POPULACJI NORNICY RUDEJ}

\section{Streszczenie}

W izolowanej na wyspie (na jeziorze Bełdany) populacji nornicy rudej Clethrionomys glareolus (Schreber, 1780) przeprowadzono badanie wplywu zwiększonej bazy pokarmowej na masę C. glareolus i przeżywalność osobników. W latach 1966-1969 populacja bytowała w warunkach naturalnych, a w latach 1973-1974 zwiększono jej bazę pokarmową przez podawanie w nadmiarze owsa. $\mathrm{Z}$ wcześniej- 
szych badań (Andrzejewski \& Mazurkiewicz, 1976; Mazurkiewicz, 1981) wynika, że w okresie eksperymentu terenowego liczebność populacji nornicy była 3 do 6 razy wyższa niż w latach 1966-1969 (Andrzejewski \& Rajska, 1972; Gliwicz, 1975; Bujalska, 1975) (Ryc. 1, Tabela 1).

Stwierdzono, że w okresie eksperymentu masa ciała osobników była istotnie wyższa $(17,2 \mathrm{~g})$ niż $\mathrm{w}$ latach $\mathrm{z}$ naturalną bazą pokarmową $(13,9 \mathrm{~g}),(0,001<P<0,01)$ (Ryc. 2, Tabela 2). Porównano przyrost masy ciała osobników w środowiskach suchych (Tilio-Carpinetum) i wilgotnych (Circaeo-Alnetum i Salici-Franguletum). W latach 1966-1969 przyrost masy był zawsze większy u osobników ze środowiska wilgotnego, natomiast $w$ latach eksperymentu - na skutek zwiększenia przyrostu $\mathrm{w}$ środowisku suchym był on jednakowy w obu środowiskach (Ryc. 3). W latach eksperymentu (1973-1974) osobniki należące do urodzonej wczesną wiosną kohorty $\mathrm{K}_{1}$ osiągały wyższą masę ciała, niezależnie od liczebności populacji (Tabela 3).

W latach o naturalnej bazie pokarmowej najniższa przeżywalność wystąpiła w roku 1969, który cechował się najniższą liczebnością, natomiast najwyższą przeżywalność zanotowano w roku 1968, kiedy liczebność populacji była najwyższa. Przeżywalność w latach eksperymentu była wyższa niż w latach 1966-1969 (Ryc. 4). 